Terbit online pada laman web jurnal : http://teknosi.fti.unand.ac.id/

\title{
Literatur Review Hubungan Budaya Organisasi dan Berbagi Pengetahuan dalam Kesuksesan Implementasi Sistem Informasi
}

\author{
Nina Fadilah Najwa ${ }^{a}$, Afifah Nurul Izzati ${ }^{b}$ \\ ${ }^{a b}$ Magister Sistem Informasi, Fakultas Teknologi Informasi,dan Komunikasi Institut Teknologi Sepuluh Nopember Surabaya
}

\begin{tabular}{|c|}
\hline INFORMASI ARTIKEL \\
\hline $\begin{array}{l}\text { Sejarah Artikel: } \\
\text { Diterima Redaksi: } 10 \text { Maret } 2018 \\
\text { Revisi Akhir: } 20 \text { April } 2018 \\
\text { Diterbitkan Online: } 28 \text { April } 2018\end{array}$ \\
\hline KATA KUNCI \\
\hline Knowledge Sharing, \\
\hline $\begin{array}{l}\text { Organizational Culture, } \\
\text { Information System }\end{array}$ \\
\hline KORESPONDENSI \\
\hline $\begin{array}{l}\text { Telepon: - } \\
\text { E-mail: nina.fadilah.najwa16@mhs.its.ac.id }\end{array}$ \\
\hline
\end{tabular}

\section{PENDAHULUAN}

Setiap organisasi memiliki budaya organisasi yang berpengaruh pada cara pegawai berfikir, bertindak, dan merespon terhadap misi proses peningkatan kinerja guna mencapai visi organisasi. Dalam pencapaian visi organisasi memerlukan keberanian dalam melakukan perubahan salah satunya dengan pengadopsian sistem informasi yang berguna untuk mendukung kinerja organisasi. Adapun salah satu kunci kesuksesan implementasi sistem informasi tersebut dengan melakukan sharing pengetahuan terkait sistem yang akan diimplementasi berdasarkan budaya organisasi sehingga seluruh level organisasi dapat mendukung dan dapat bekerjasama dengan baik dalam pembangunan sistem [1]. Beberapa faktor budaya organisasi yang telah diidentifikasi memiliki keterkaitan erat dengan berbagi pengetahuan adalah komitmen manajer, kepintaran emosional, ketakutan, struktur organisasi yang hirarki atau clan, lemahnya jaringan sosial, perbedaan usia, perbedaan jenis kelamin, kurangnya sumber daya, motif konflik, ketidakpastian, rasa rendah diri, penanganan konflik dan lingkungan umum dalam pekerjaan, dan sebagainya [2]. Dari faktor tersebut, dapat diketahui masalah utama dalam berbagi pengetahuan dalam suatu organisasi disebabkan oleh budaya organisasi.

Banyaknya faktor dan sudut pandang budaya organisasi menyebabkan perubahan sulit dilakukan karena rentannya dalam penolakan untuk berubah. Pada proyek sistem informasi, seringkali pihak manajerial harus mempertimbangkan budaya organisasi dalam pengimplementasiannya. Hal ini karena, intervensi dalam kesuksesan proyek tersebut dipengaruhi oleh minat dan budaya organisasi dan kurangnya pemahaman dari outcome pengimplementasian [3]. Dalam mengatasi perubahan, peran manajerial dan pegawai dalam menangkap dan menyebarkan pengetahuan tentang proyek dan perubahan yang terjadi tersebut perlu dikelola dengan baik.

Menurut Hyde dan Wilson (2004) bahwa budaya organisasi berdampak pada terbatasnya kerjasama dalam pengimplementasian sistem informasi diantara pegawai selama pekerjaan dari proses peningkatan sedang dijalani. Sehingga, budaya organisasi mempengaruhi kemauan dan prilaku dari pegawai dalam aspek berbagi pengetahuan sesuai dengan penelitian yang telah dilakukan oleh Jung-Chieh lee, dkk (2016) terdapat hubungan yang positif antara budaya organisasi (clan- 
type organizational culture dan hierarchy-type organizational culture) dan berbagi pengetahuan yang berdampak pada kesuksesan implementasi Software Process Improvement (SPI) [4]. Penelitian lain yang juga membahas keterkaitan budaya organisasi dan berbagi pengetahuan adalah Shao, Feng dan Liu (2012) dari aspek pembangunan budaya, budaya grup, budaya hirarki dan budaya rasional berhubungan dengan berbagi pengetahuan dan kesuksesan implementasi ERP yang merupakan salah satu jenis dari sistem informasi [5]. Dari kedua penelitian tersebut juga melihat peran manajer dalam membangun kepercayaan (trust) kepada pegawai dengan berbagi pengetahuan.

Menurut penelitian terdahulu yang telah dilakukan, dengan menyebarkan atau berbagi pengetahuan dalam suatu organisasi sangatlah membantu para stakeholder saat proses pengimplementasian sistem informasi dalam mencegah kesalahan yang sama, mengurangi ketergantungan kepada pegawai yang memiliki pengetahuan yang kritis dalam organisasi, meningkatkan integritas kompetensi individual (termasuk pengetahuan, pengalaman, dan skill), dan membantu dalam membuat keputusan [4]. Melalui berbagi pengetahuan, pegawai akan memahami lebih dalam mengenai alasan mengapa perlu menerapkan sistem informasi guna untuk mendukung tercapainya visi dan eksistensi dari organisasi tersebut.

Berdasarkan penjabaran diatas, maka terdapat dua pertanyaan penelitian (research question) yang akan diulas pada paper ini, yaitu: (1) Penelitian apa saja yang mengangkat topik hubungan antara budaya organisasi dan berbagi pengetahuan? (2) Bagaimana dampak dari hubungan budaya organisasi dan berbagi pengetahuan dalam kesuksesan implementasi sistem informasi?. Untuk menjawab pertanyaan kedua pertanyaan ini, akan dibahas lebih detail dan pencarian paper mengenai budaya organisasi yang berhubungan dengan berbagi pengetahuan dan bagaimana keterkaitannya dengan implementasi sistem informasi.

\section{TINJAUAN PUSTAKA}

\subsection{Berbagi Pengetahuan}

Budaya organisasi didefinisikan dengan tipe dari cara orang berfikir, yang memiliki pengaruh secara langsung dengan cara mereka berprilaku. Sedangkan menurut Schein (1985), budaya organisasi adalah keyakinan, nilai, dan asumsi yang disebarkan oleh anggota dalam suatu organisasi [6]. Secara khusus, budaya organisasi menjadi acuan referensi untuk perubahan organisasi. Ketika organisasi memiliki perbedaan budaya, orang-orang yang memiliki persepsi dan interpretasi yang berbeda dari perubahan organisasi, akan berdampak pada penerimaan pegawai terhadap perubahan. Oleh karena itu, budaya organisasi sangatlah penting untuk kesuksesan dari proyek yang dapat memberikan perubahan pada organisasi. Sehingga perlu dilakukan analisa mengenai budaya organisasi dalam pengadopsian Sistem Informasi seperti penelitian Cooper bahwa ketika terjadi konflik IT dengan budaya organisasi, pengimplementasian akan mengalami penolakan dengan dua cara yaitu sistem akan ditolak atau sistem dimodifikasi menyesuaikan dengan budaya organisasi yang ada.

Budaya organisasi memiliki beberapa dimensi menurut Denison and Spreitzer (1991) berdasarkan Competing Values Framework

2 Nina Fadilah Najwa
(CVF) yaitu budaya grup, pembangunan budaya, budaya rasional, budaya hirarki, budaya $\mathrm{k}$

eseimbangan [6]. Dari dimensi tersebut, terdapat hubungan yang positif dalam peningkatan nilai budaya organisasi dapat dilakukan untuk efektifitas organisasi. Sehingga dengan mengenali tipe-tipe organisasi dalam mengadopsi sistem informasi akan lebih memudahkan dalam melakukan strategi perubahan yang cocok.

Setiap organisasi memiliki budaya yang merupakan sebuah cara bagi organisasi untuk mempelajari faktor lingkungan. Budaya organisasi yang melekat berdasarkan cara pandang terhadap sesuatu, asumsi yang bersama-sama telah terbentuk, opini dan sebagainya. Sehingga, budaya organisasi akan berpengaruh kepada prilaku dan penerimaan terhadap perubahan yang akan dilakukan. Bagi pengembang sistem dan manajerial, budaya organisasi menjadi langkah awal yang harus didefinisikan dan dianalisa agar tujuan organisasi bisa terwujud dan meminimalisir resiko penolakan dari budaya yang telah lama ada pada organisasi tersebut.

\subsection{Manajemen Pengetahuan dan Berbagi Pengetahuan}

Pengetahuan yang dimiliki oleh organisasi merupakan aset penting yang harus dikelola dengan baik demi mencapai tujuan organisasi dengan efektif dan efisien serta mempertahankan eksistensi organisasi dan bermanfaat sebagai peningkatan kompetitif. Menurut Nonaka dan von Krough (2009) bahwa pengetahuan adalah sebagai persepsi individual, kemampuan dan pengalaman, yang seluruhnya ketergantungan kepada pengalaman apa yang memberikan arti dan bermakna [7]. Salah satu aspek penting dalam pengetahuan adalah keterkaitan personal dan konteks sosial. Hubungan antara persepsi individual dari pengetahuan pada level organisasi (proses pengetahuan) memiliki tahapan yang dimulai dari membuat atau menciptakan pengetahuan dengan menggunakan pengetahuan yang ada, transfer pengetahuan, dan membagikan pengetahuan, dan menyimpan, mengkodifikasikan pengetahuan tersebut untuk dapat dimanfaatkan.

Tahapan yang krusial dan sulit dalam proses pengetahuan adalah mengkonversikan pengetahuan tacit ke dalam pengetahuan explisit. Pengetahuan tacit adalah pengetahuan yang tidak dapat disusun dan berdasarkan pengalaman, intuisi, dan kemampuan pribadi. Sedangkan pengetahuan yang explicit adalah pengetahuan yang telah dikumpulkan serta diterjemahkan ke dalam suatu bentuk dokumentasi sehingga lebih mudah untuk ditransfer atau dibagikan kepada orang lain dalam bentuk dokumentasi karena umumnya merupakan pengetahuan yang bersifat teori. Berbagi pengetahuan dalam proyek sistem informasi menjadi kebutuhan untuk mensukseskan implementasi sistem informasi [8]. Sulitnya mendeteksi pengetahuan yang tacit karena berada pada manusia itu sendiri sebagai kunci pengetahuan. Dalam organisasi diperlukan pengelolaan pengetahuan baik tacit maupun explicit. Pengelolaan tacit dilakukan dapat dengan cara berbagi pengetahuan seperti pelatihan ataupun dokumen-dokumen pendukung. Sumber daya manusia yang memiliki pengetahuan tacit perlu di explicit karena sewaktu-waktu orang tersebut keluar dari organisasi, maka organisasi tidak kehilangan pengetahuannya (dapat menjalankan

https://doi.org/10.25077/TEKNOSI.v4i1.2018.001-008 
proses bisnisnya seperti biasa). Sehingga untuk mendukung transformasi tacit ke explicit dan untuk memfasilitasi proses pengetahuan organisasi diperlukan manajemen pengetahuan dengan proses Socialization, Externalization, Combination, dan Internalization (SECI) Model seperti di bawah ini [9]:

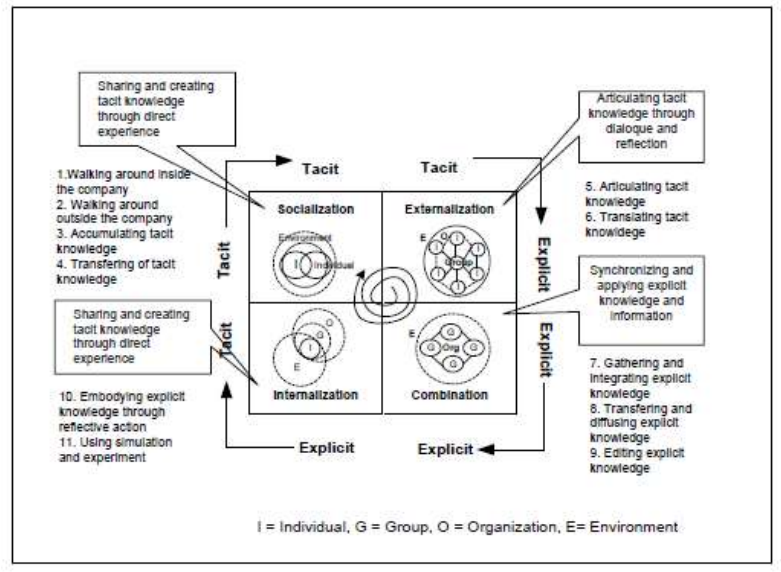

Gambar 1. SECI Model dalam Manajemen Pengetahuan [9]

Socialization adalah tahapan dalam mengkonversikan pengetahuan tacit ke pengetahuan tacit. Hal ini menggantikan dalam pertemuan sosial yang informal dan termasuk dalam lingkup organisasi. Contoh interaksi sosialisasi adalah antara pelanggan dan pemasok. Faktor empati adalah salah satu faktor terpenting dalam proses sosialisasi. Externalization adalah tahap konversi pengetahuan tacit ke pengetahuan explicit dengan artikulasi berbagi pengetahuan. Combination adalah tahap ketika pengetahuan explicit individual telah terkumpul dalam sekumpulan sistematik pengetahuan explicit. Sedangkan internalization adalah proses mengubah pengetahuan explicit menjadi pengetahuan tacit yang dikenal dengan "learning by doing".

\subsection{Budaya Organisasi dan Berbagi Pengetahuan}

Telah banyak organisasi yang telah menerapkan ERP yang merupakan Sistem Informasi yang mengintegrasikan proses, prosedur, orang dan data. Dalam pengimplementasiannya, terdapat hal-hal yang perlu diperhatikan termasuk budaya organisasi yang berpengaruh pada minat pegawai dalam berbagi pengetahuan. Keterkaitan antara budaya organisasi dan berbagi pengetahuan telah banyak dilakukan penelitian, seperti penelitian yang dilakukan oleh Chou, dkk (2014) bahwa dari survey yang dilakukan pada 53 perusahaan di taiwan terdapat beberapa faktor budaya organisasi (motivasi intristik, efikasi diri, social capital) yang berdampak pada berbagi pengetahuan dalam lingkungan pegawai dan sangat berpengaruh pada kesuksesan implementasi ERP[10].

Faktor kepercayaan juga salah satu faktor yang mempengaruhi dalam berbagi pengetahuan yang dimiliki, karena bentuk pengetahuan yang tacit sehingga dalam berkolaborasi dengan pegawai lain memerlukan rasa saling percaya dan kepercayaan diri terhadap kemampuan dari pemberi pengetahuan[11][12]. Pengetahuan tacit tersebut dapat diidentifikasi berdasarkan tipe organisasi yaitu clan, adhocracy, market dan hierarchy yaitu dengan tipe clan memiliki hubungan positif dengan berbagi

https://doi.org/10.25077/ TEKNOSI.v4i1.2018.001-008 pengetahuan sedangkan tipe market dan hierarcy memiliki hubungan negatif dengan berbagi pengetahuan [13]. Selain faktor kepercayaan, terdapat budaya organisasi berupa penghargaan yang berpengaruh dalam berbagi pengetahuan. Dengan memberikan penghargaan kepada pegawai yang memiliki pengetahuan akan meningkatkan keinginannya dalam mentransferkan, sedangkan yang mendapat pengetahuan juga akan lebih mudah jika diberikan penghargaan atau hadiah [14].

\section{METODOLOGI}

Penyusunan paper ini melalui beberapa tahapan berdasarkan panduan dari Kitchenham (2009). Adapun dasar dari melakukan ulasan literatur ini adalah untuk mengumpulkan dan mengevaluasi seluruh penelitian yang berhubungan dengan pertanyaan yang diangkat untuk dibahas, kemudian menghasilkan ketidakbiasan, dan teruji. Adapun tujuan dari literature review ini menurut Kitchenham, adalah untuk mengidentifikasi, mengevaluasi, dan penelitian yang tersedia terkait dengan pertanyaan pada penelitian atau topik, atau fenomena yang menarik [15].

\subsection{Pertanyaan Penelitian}

Fokus ulasan mengenai faktor budaya organisasi dan manajemen pengetahuan yang berdampak pada kesuksesan implementasi sistem informasi, perlu dilakukan spesifikasi atau fokus review literatur dengan pertanyaan penelitian (research question). Adapun pertanyaan yang akan dijawab adalah:

1. RQ1 : Penelitian apa saja yang mengangkat topik hubungan antara budaya organisasi dan berbagi pengetahuan?

2. RQ2 : Bagaimana dampak dari budaya organisasi dan berbagi pengetahuan dalam kesuksesan implementasi sistem informasi?

\subsection{Sumber Literatur}

Dalam pencarian jurnal/paper yang berhubungan dengan topik yang diangkat, maka sumber yang digunakan untuk pencarian literatur dibatasi pada basis data pada jurnal internasional, yaitu:

1. Science direct (www.sciencedirect.com)

2. IEEE (ieeexplore.ieee.org)

3. Emerald (emeraldinsight.com)

\subsection{Kata Kunci Pencarian Literatur}

Berikut kata kunci yang digunakan untuk melakukan pencarian literatur yang terkait mencakup beberapa kata kunci sebagai berikut :

1. Organizational Culture

2. Knowledge Sharing

3. Organizational culture and Knowledge Management

\subsection{Penilaian Literatur}

Berdasarkan panduan pada Walia dan Caver (2009) terdapat kriteria inclusion dan exclusion sebagai pemilihan paper yang akan dibahas [15]:

Kriteria Inclusion:

1. Paper yang didapat termasuk dalam kategori social and behaviour science, information system management, computers in human behaviour, technology forecasting and social change, project management, yang pada 
umumnya termasuk pada ranah bidang sistem informasi.

2. Isi paper sesuai dengan yang akan dibahas dengan membaca judul penelitian dan abstrak penelitian, tanpa mengunduh. Jika dikira sesuai maka paper akan diunduh dan dikumpulkan dalam satu folder untuk dilakukan filter selanjutnya.

3. Tahun publikasi paper yang dibahas minimal tahun 2011.

4. Berupa jurnal atau conferences.

5. Paper yang digunakan berbahasa inggris.

6. Pencarian literatur pada basis data terkemuka seperti IEEE, Science direct dan Emerald.

7. Diutamakan tipe penelitian berupa research paper atau dengan menggunakan metodologi survey.

Kriteria Exclusion:

1. Topik tidak berhubungan dengan pembahasan, dan tidak mencakup pertanyaan penelitian.

2. Tidak berhubungan dengan kesuksesan sistem informasi atau diluar bidang sistem informasi.

3. Bahasa pengantar paper tidak menggunakan bahasa inggris.

4. Selain jurnal dan conferences dengan tahun terbit dibawah tahun 2011. Referensi yang diutamakan untuk digunakan adalah jurnal.

Berikut ini pemilihan dari total yang diperoleh sehingga pengambilan paper yang akan digunakan:

Tabel 1. Hasil Pencarian Literatur

\begin{tabular}{llll}
\hline Kata Kunci (Keyword) & $\begin{array}{l}\text { Science } \\
\text { direct }\end{array}$ & IEEE & Emerald \\
\hline Organizational Culture & 539 & 321 & 512 \\
Knowledge Sharing & 1801 & 311 & 854 \\
Organizational culture & 402 & 19 & 73 \\
and Knowledge Sharing & & & \\
\hline
\end{tabular}

Terlihat pada tabel di atas bahwa science direct lebih banyak terdapat paper terkait dengan pembahasan berdasarkan kata kunci yang dicari pada basis data. Dari kriteria inclusion dan exclusion, maka hasil dari seleksi paper yang digunakan adalah sebagai berikut:

Tabel 2. Hasil Seleksi

\begin{tabular}{lll}
\multicolumn{1}{c}{ Basis Data } & Total Retrieved & Final Selection \\
\hline Science direct & 2742 & 10 \\
IEEE & 651 & 4 \\
Emerald Insight & 1439 & 7 \\
Referensi relevan & - & 1 \\
\hline
\end{tabular}

Berdasarkan seleksi yang dilakukan, didapatkan paper yang digunakan berjumlah 22 paper. Science direct diperoleh 10 paper, IEEE diperoleh 4 paper, Emerald Insight diperoleh 7 paper dan 1 paper tambahan yang dianggap relevan yang digunakan untuk penyusunan metodologi dalam mengulas literatur. Selanjutkan dilakukan ekstraksi data untuk ketahapan mengulas literatur.

\subsection{Ekstraksi Data}

Tujuan dari data ekstraksi adalah untuk konsisten dan keakuratan dari ekstraksi informasi. Adapun data yang termasuk dalam ekstraksi adalah identifikasi, nama penulis, tahun publikasi, sumber, referensi, metodologi pengumpulan data, analisis data dan konsep. Pencarian paper tambahan juga didapatkan dari

4 Nina Fadilah Najwa referensi dari main paper yang menjadi landasan ide dari pembuatan review literatur ini.

\section{HASIL DAN PEMBAHASAN}

\subsection{RQ1: Penelitian apa saja yang mengangkat topik hubungan antara budaya organisasi dan berbagi pengetahuan?}

Telah banyak penelitian yang membahas faktor budaya organisasi yang mempengaruhi dalam kesuksesan sistem informasi, dan pengaruh dari budaya organisasi dalam minat pegawai dalam berbagi pengetahuan. Berbagi pengetahuan ini juga berpengaruh dengan kesuksesan sistem informasi. Untuk lebih jelasnya tentang bagaimana hubungan antara faktor-faktor budaya organisasi dan hubungannya dengan berbagi pengetahuan dalam kesuksesan implementasi sistem informasi, berikut ini adalah sejumlah penelitian terkait:

Tabel 3. Penelitian Terkait Hubungan Budaya Organisasi dan Berbagi Pengetahuan

\begin{tabular}{|c|c|c|c|c|}
\hline $\begin{array}{l}\mathrm{N} \\
\mathrm{o}\end{array}$ & $\begin{array}{l}\text { Faktor Budaya } \\
\text { Organisasi }\end{array}$ & $\begin{array}{l}\text { Hubungan } \\
\text { dengan berbagi } \\
\text { pengetahuan } \\
\text { (tacit/explicit) }\end{array}$ & $\begin{array}{l}\text { Tipe } \\
\text { penelitian }\end{array}$ & $\begin{array}{l}\text { Sumber } \\
\text { (peneliti } \\
\& \text { tahun) }\end{array}$ \\
\hline 1 & $\begin{array}{l}\text { a. Clan Culture } \\
\text { (teamwork, } \\
\text { trust, employee } \\
\text { involvement } \\
\text { and } \\
\text { participation, } \\
\text { high } \\
\text { organizational } \\
\text { commitment to } \\
\text { employees) } \\
\text { b. Hierarchy } \\
\text { culture } \\
\text { (regulation, } \\
\text { SOP, hierarchy } \\
\text { structure) }\end{array}$ & $\begin{array}{l}\text { Tacit } \\
\text { knowledge dan } \\
\text { prilaku } \\
\text { keinginan } \\
\text { berbagi } \\
\text { pengetahuan } \\
\text { yang } \\
\text { dipengaruhi } \\
\text { peran manajer } \\
\text { atas untuk } \\
\text { kesuksesan } \\
\text { implementasi } \\
\text { ERP. }\end{array}$ & survey & $\begin{array}{l}\text { Lee, } \\
\text { Jung- } \\
\text { Chieh., } \\
\text { dkk } \\
(2016) \\
{[4]}\end{array}$ \\
\hline 2 & $\begin{array}{l}\text { a. Development } \\
\text { culture } \\
\text { (growth, } \\
\text { stimulation, } \\
\text { creativity, } \\
\text { resources } \\
\text { acquisition) } \\
\text { b. Group Culture } \\
\text { (belonging,atta } \\
\text { chment, } \\
\text { cohesiveness, } \\
\text { trust, and } \\
\text { participation) } \\
\text { c. Hierarchy } \\
\text { culture } \\
\text { (uniformity, } \\
\text { security, order, } \\
\text { rules, control, } \\
\text { coordination, } \\
\text { regulation and } \\
\text { efficiency) } \\
\text { d. Rational } \\
\text { Culture } \\
\text { (planning, } \\
\text { productivity, } \\
\text { efficiency, } \\
\text { successful } \\
\text { achievement of } \\
\text { predetermined } \\
\text { goals) }\end{array}$ & $\begin{array}{l}\text { Tacit dan } \\
\text { explicit } \\
\text { Knowledge } \\
\text { berpengaruh } \\
\text { pada } \\
\text { kesuksesan } \\
\text { implementasi } \\
\text { ERP. }\end{array}$ & survey & $\begin{array}{l}\text { Shao, } \\
\text { Zhen., } \\
\text { dkk } \\
(2012) \\
{[16]}\end{array}$ \\
\hline
\end{tabular}

https://doi.org/10.25077/TEKNOSI.v4i1.2018.001-008 


\begin{tabular}{|c|c|c|c|c|}
\hline $\begin{array}{l}\mathrm{N} \\
\mathrm{o}\end{array}$ & $\begin{array}{l}\text { Faktor Budaya } \\
\text { Organisasi }\end{array}$ & $\begin{array}{l}\text { Hubungan } \\
\text { dengan berbagi } \\
\text { pengetahuan } \\
\text { (tacit/explicit) }\end{array}$ & $\begin{array}{l}\text { Tipe } \\
\text { penelitian }\end{array}$ & $\begin{array}{l}\text { Sumber } \\
\text { (peneliti } \\
\& \text { tahun) }\end{array}$ \\
\hline 3 & $\begin{array}{lr}\begin{array}{l}\text { Social r } \\
\text { trust }\end{array} & \text { capital } \\
\text { intrinsic } & \\
\text { motivation, } & \text { self- } \\
\text { efficacy } & \end{array}$ & $\begin{array}{l}\text { Tacit knowledge } \\
\text { dan kesuksesan } \\
\text { setelah } \\
\text { implementasi } \\
\text { ERP }\end{array}$ & survey & $\begin{array}{l}\text { Chou, } \\
\text { Huey- } \\
\text { Wen., } \\
\text { dkk } \\
(2014) \\
{[10]}\end{array}$ \\
\hline 4 & Trust & $\begin{array}{l}\text { Tacit } \\
\text { Knowledge }\end{array}$ & survey & $\begin{array}{l}\text { Chen, } \\
\text { Ying- } \\
\text { Hueih., } \\
\text { dkk } \\
(2014) \\
{[11]}\end{array}$ \\
\hline 5 & Trust & $\begin{array}{l}\text { Tacit } \\
\text { Knowledge }\end{array}$ & survey & $\begin{array}{l}\text { Swift, } \\
\text { Peter } \\
\text { E.(2013)[ } \\
12]\end{array}$ \\
\hline 6 & $\begin{array}{l}\text { a. Clan culture } \\
\text { Culture } \\
\text { (teamwork, } \\
\text { trust, employee } \\
\text { involvement and } \\
\text { participation, } \\
\text { high } \\
\text { organizational } \\
\text { commitment to } \\
\text { employees) } \\
\text { b. Adhoracy } \\
\text { culture } \\
\text { (enterprenerial } \\
\text { and creative } \\
\text { workplace, } \\
\text { effective } \\
\text { leadership } \\
\text { visionary, } \\
\text { innovative, risk- } \\
\text { oriented) } \\
\text { c. Market culture } \\
\text { (competitivenes } \\
\text { s, productivity) } \\
\text { e. Hierarchy } \\
\text { culture } \\
\text { (uniformity, } \\
\text { security, order, } \\
\text { rules, control, } \\
\text { coordination, } \\
\text { regulation and } \\
\text { efficiency) } \\
\text { d. Organisasi yang } \\
\text { tidak memiliki } \\
\text { budaya } \\
\text { organisasi yang } \\
\text { lebih dominan. }\end{array}$ & $\begin{array}{l}\text { Tacit } \\
\text { Knowledge } \\
\text { (komunikasi } \\
\text { organisasi, } \\
\text { interaksi } \\
\text { personal, } \\
\text { mentoring, } \\
\text { kemauan } \\
\text { berbagi } \\
\text { pengetahuan) }\end{array}$ & survey & $\begin{array}{l}\text { Suppiah, } \\
\text { Visvaling } \\
\text { am.,Sand } \\
\text { hu, } \\
\text { Manjit } \\
\text { Singh(20 } \\
\text { 11) [17] }\end{array}$ \\
\hline 7 & $\begin{array}{l}\text { Rewards, } \\
\text { motivation, group } \\
\text { culture, open } \\
\text { organizational } \\
\text { culture. }\end{array}$ & $\begin{array}{l}\text { Budaya } \\
\text { organisasi tidak } \\
\text { berpengaruh } \\
\text { secara langsung } \\
\text { kepada minat } \\
\text { berbagi } \\
\text { pengetahuan } \\
\text { tetapi } \\
\text { berpengaruh } \\
\text { langsung } \\
\text { dengan } \\
\text { mendapatkan } \\
\text { pengetahuan } \\
\text { melalui reward. }\end{array}$ & survey & $\begin{array}{l}\text { Durmuso } \\
\text { glu, } \\
\text { Serdar., } \\
\text { dkk } \\
(2014) \\
{[14]}\end{array}$ \\
\hline 8 & Dependeces, trust. & $\begin{array}{l}\text { Tacit } \\
\text { Knowledge } \\
\text { dalam proyek } \\
\text { sistem } \\
\text { informasi. }\end{array}$ & survey & $\begin{array}{l}\text { Park, } \\
\text { Jun-Gi., } \\
\text { Lee, } \\
\text { Jungwoo } \\
(2014) \\
{[8]}\end{array}$ \\
\hline
\end{tabular}

\begin{tabular}{|c|c|c|c|c|}
\hline $\begin{array}{l}\mathrm{N} \\
\mathrm{o}\end{array}$ & $\begin{array}{l}\text { Faktor Budaya } \\
\text { Organisasi }\end{array}$ & $\begin{array}{l}\text { Hubungan } \\
\text { dengan berbagi } \\
\text { pengetahuan } \\
\text { (tacit/explicit) }\end{array}$ & $\begin{array}{l}\text { Tipe } \\
\text { penelitian }\end{array}$ & $\begin{array}{l}\text { Sumber } \\
\text { (peneliti } \\
\& \text { tahun) }\end{array}$ \\
\hline 9 & $\begin{array}{l}\text { Trust, social, } \\
\text { organizational }\end{array}$ & $\begin{array}{l}\text { Tacit dan } \\
\text { Explicit } \\
\text { Knowledge, } \\
\text { manajerial harus } \\
\text { menciptakan } \\
\text { budaya berbagi } \\
\text { pengetahuan } \\
\text { untuk mencapai } \\
\text { tujuan bisnis. }\end{array}$ & survey & $\begin{array}{l}\text { Makhube } \\
\text { le, Lean., } \\
\text { dkk } \\
(2012) \\
{[18]}\end{array}$ \\
\hline 10 & $\begin{array}{l}\text { Hierarcy culture, } \\
\text { rational culture, } \\
\text { group culture. }\end{array}$ & $\begin{array}{l}\text { Tacit dan } \\
\text { Explicit berbagi } \\
\text { pengetahuan } \\
\text { dalam konteks } \\
\text { ERP }\end{array}$ & survey & $\begin{array}{l}\text { Shao, } \\
\text { Zhen., } \\
\text { dkk } \\
(2015) \\
{[16]} \\
\end{array}$ \\
\hline 11 & $\begin{array}{l}\text { Culture: } \\
\text { Collaboration, } \\
\text { Learning and } \\
\begin{array}{l}\text { Development } \\
\text { orientation, } \\
\text { management } \\
\text { support }\end{array}\end{array}$ & $\begin{array}{l}\text { Tacit } \\
\text { Knowledge }\end{array}$ & survey & $\begin{array}{l}\text { Islam, } \\
\text { Md } \\
\text { Zahidul } \\
\text { (2015) } \\
{[19]}\end{array}$ \\
\hline 12 & $\begin{array}{l}\text { Goal } \\
\text { culture, } \\
\text { oriented culture }\end{array}$ & $\begin{array}{ll}\text { Tacit } & \text { dan } \\
\text { Explicit } & \\
\text { knowledge } & \end{array}$ & $\begin{array}{l}\text { Review } \\
\text { Literature }\end{array}$ & $\begin{array}{l}\mathrm{Al} \\
\text { Mehairi, } \\
\text { Hanan } \\
\text { Abdulla } \\
(2013) \\
{[20]}\end{array}$ \\
\hline
\end{tabular}

Penelitian yang dijelaskan pada tabel 3 telah membuktikan bahwa pengetahuan tacit dan explicit dalam minat berbagi pengetahuan dipengaruhi oleh faktor budaya organisasi. Kedua komponen tersebut mempengaruhi kesuksesan implementasi sistem informasi karena budaya yang paling banyak disebutkan dalam berbagi pengetahuan antara pegawai tercipta berdasarkan prinsip saling percaya (trust). Pengetahuan explicit merupakan pengetahuan formal dan sistematis yang dapat diperoleh dari membaca buku manual proyek, ataupun diskusi dalam tim. Sedangkan pengetahuan tacit lebih kepada pengetahuan yang dimiliki oleh seseorang, subjektif, dan sulit untuk diungkap dan dikomunnikasikan. Sehingga dalam mengkonversikan pengetahuan tacit ke explicit memerlukan proses berbagi pengetahuan.

Tipe-tipe organisasi juga mempengaruhi pola berbagi hal ini karena prilaku yang berbeda dengan adanya kesenjangan antara pengetahuan tacit (yang terdapat pada masing-masing individu) akan sulit untuk diberikan kepada orang lain, jika yang memiliki pengetahuan tidak memiliki hubungan ataupun jaringan. Menurut penelitian yang dilakukan oleh Amayah (2013) [21], bahwa dengan mengidentifikasi faktor yang mempengaruhi berbagi pengetahuan ini dapat membantu organisasi yang ingin mencapai tujuan organisasinya dengan menciptakan budaya berbagi pengetahuan [21]. Budaya berbagi pengetahuan akan sangat berguna jika saat pengimplementasian sebuah sistem informasi, para stakeholder lebih mudah dalam mengelola perubahan karena persebaran pengetahuan yang merata dan dapat dipahami maksud dan tujuannya dari keputusan implementasi sistem informasi tersebut. 


\subsection{RQ2: Bagaimana dampak dari budaya organisasi dan berbagi pengetahuan dalam kesuksesan implementasi sistem informasi?}

Setiap organisasi memiliki budaya organisasi yang menjadi sebuah nilai dan identitas pembeda dari organisasi lainnya. Budaya organisasi terbentuk dari pola pikir, prilaku dan lingkungan para pegawai yang dibentuk dari berbagai faktorfaktor budaya organisasi yang telah lama tertanam sehingga menjadi sebuah hal yang sulit untuk dirubah dari organisasi tersebut. Seperti tipe budaya organisasi yang diulas oleh Al mehairi (2013) [20], bahwa ada organisasi yang memiliki budaya seperti goal oriented culture dengan lebih berfokus pada kebutuhan yang harus dipenuhi, kemauan melakukan metode atau melakukan perubahan yang tentunya terdapat resiko. Goal oriented culture merupakan tipe budaya yang tidak memperhatikan proses yang digunakan untuk mendapatkan tujuan, tetapi lebih memperhatikan outcome dari perubahan yang dilakukan [20]. Sebaliknya, terdapat juga organisasi yang memiliki budaya means oriented culture yang orang-orang didalamnya enggan dalam melakukan perubahan karena takut mengambil resiko, hanya melakukan usaha-usaha atau pekerjaan yang statis dan menjadi rutinitas yang nyaman.

Tipe budaya organisasi means oriented culture ini tentunya rentan terhadap penolakan karena budayanya tidak ingin mengambil resiko dengan melakukan perubahan sehingga dianggap sebagai budaya yang lemah. Penerapan sebuah sistem informasi tentunya akan memberikan perubahan, baik dari segi prosedur kerja, perubahan struktur organisasi, maupun perubahan lainnya yang berpengaruh pada kegiatan yang lazimnya dikerjakan tetapi dengan implementasi akan dirombak. Salah satu tantangan bagi stakeholder jika berhadapan dengan organisasi yang memiliki means oriented culture ini, karena akan menghambat tujuan dan peningkatan kinerja dari organisasi. Adapun faktor budaya organisasi yang paling berpengaruh dari segi tipe organisasi (struktural : clan, hierarcy, dan sebagainya) yang paling banyak dibahas dari sisi kepercayaan para pegawai dalam berbagi. Dalam sebuah grup atau tim yang kooperatif, akan membangun ikatan saling percaya sehingga dalam berbagi pengetahuan (kolaborasi antara tacit dan explicit) akan lebih mudah. Kemampuan dalam berbagi pengetahuan tersebut akan membangun bagaimana mengatasi permasalahan perubahan dalam organisasi sehingga kesuksesan untuk mendapatkan outcome dari implementasi sebuah sistem informasi akan tercapai.

Salah satu tujuan utama dari berbagi pengetahuan adalah untuk tersampaikannya pengetahuan dari personal pegawai kepada pegawai lainnya sehingga memiliki pemahaman yang sama [22]. Organisasi yang memiliki kemampuan berbagi pengetahuan yang besar akan lebih baik dalam menanggapi perubahan lingkungan untuk peningkatan kinerja. Bagaimanapun, kesuksesan dalam berbagi pengetahuan ini akan terbatasi dengan kemampuan pegawai dalam memanajemen sumber daya pengetahuan yang ada untuk dapat disebarkan kepada pegawai lainnya. Sehingga keefektifan dalam berkomunikasi merupakan faktor yang mendukung dalam penyebaran pengetahuan tersebut. Adapun cara untuk mencapai komunikasi yang berguna untuk mendorong kesuksesan dalam berbagi pengetahuan dengan keadaan budaya organisasi yang ada dapat melalui pelatihan yang spesifik dan

6 Nina Fadilah Najwa program pembangunan, pengukuran kinerja competence-based, memberikan rewards, menggali kemampuan pegawai, dan merekomendasikan pegawai yang berkompeten untuk menjadi percontohan bagi pegawai lainnya. Sehingga, dengan meningkatkan kemauan berbagi pengetahuan akan tercipta saling percaya dan meningkatkan kualitas dalam berkomunikasi diantara para pegawai.

Banyaknya faktor budaya organisasi, tentunya memberikan dampak pada kemauan pegawai yang memiliki pengetahuan tentang sistem itu untuk berbagi pengetahuan kepada pegawai lainnya. Penolakan yang terjadi pada proses implementasi sistem informasi oleh para pegawai tentunya dikarenakan kurangnya pengetahuan para pegawai tersebut tentang pentingnya dan alasan mengapa sistem itu harus diimplementasikan. Penyampaian pengetahuan tersebut harus bisa dikelola dengan baik, sehingga penyampaian pengetahuan akan sama-rata persebarannya dan mampu menciptakan komitmen yang kuat untuk sama-sama mencapai outcome dari implementasi sistem tersebut.

\section{DISKUSI}

Berdasarkan hasil temuan menjelaskan bahwa adanya faktor berbagi pengetahuan yang berpengaruh terhadap kesuksesan implementasi sistem informasi. Adanya kemampuan berbagi pengetahuan akan mendorong kemampuan suatu organisasi dalam menghadapi permasalahan yang muncul dari perubahan dalam implementasi sistem informasi. Selain itu terdapat faktor budaya organisasi yang berpengaruh terhadap kesuksesan implementasi sistem informasi, hal ini karena budaya organisasi erat kaitannya dengan pola pikir dan perilaku pegawai, yang nantinya akan berpengaruh terhadap kemampuan organisasi dalam menghadapi perubahan yang timbul dari implementasi sistem informasi. Adapun faktor berbagi pengetahuan dan budaya organisasi saling terkait dalam kesuksesan implementasi sistem informasi. Hal ini dapat dilihat dari adanya faktor budaya organisasi yang mempengaruhi pengetahuan tacit dan explicit dalam minat berbagi pengetahuan. Dengan mengidentifikasi faktor budaya organisasi yang mempengaruhi faktor berbagi pengetahuan ini, maka dapat membantu organisasi dalam mencapai tujuannya dengan menciptakan budaya berbagi pengetahuan. Adanya budaya berbagi pengetahuan dalam suatu organisasi, maka dapat mendorong kemampuan organisasi dalam menanggapi adanya perubahan yang muncul dari implementasi sistem informasi.

Faktor berbagi pengetahuan dan budaya organisasi merupakan faktor yang penting untuk dipertimbangkan dalam mencapai kesuksesan implementasi sistem informasi. Hal ini karena dengan adanya berbagi pengetahuan, maka pengetahuan dapat tersampaikan secara merata pada lingkungan stakeholder, sehingga stakeholder mempunyai pemahaman yang sama dalam implementasi sistem informasi. Pemahaman yang dimiliki oleh stakeholder akan mendorong penerimaan stakeholder terhadap perubahan yang terjadi akibat dari implementasi sistem informasi, sehingga kesuksesan untuk mendapatkan outcome dari implementasi sebuah sistem informasi akan tercapai. Selain itu adanya faktor budaya organisasi mempunyai peran penting dalam kesuksesan implementasi sistem informasi, hal ini karena budaya organisasi erat kaitanya dengan pola pikir dan perilaku stakeholder. Budaya organisasi yang lebih terbuka terhadap

https://doi.org/10.25077/TEKNOSI.v4i1.2018.001-008 
perubahan maka akan lebih mudah dalam menerima perubahan yang timbul dari implementasi sistem informasi.

Dalam sebuah budaya organisasi yang berfokus pada goal oriented, pekerja yang bekerja pada sebuah organisasi akan memperoleh sekumpulan tujuan individu dan oganisasi dengan menggunakan seluruh sumber daya yang mereka miliki untuk mendukung tujuan tersebut. Hal ini dikarenakan adanya satu tujuan yang sejalan antara pekerja dan tujuan organsisasi. Budaya organisasi juga berdampak pada penerimaan risiko, yang berarti dari budaya organisasi yang berbasis tujuan, dimana pekerja tidak takut untuk mengambil risiko [20]. Dengan menciptakan satu tujuan yang selaras dan pemahaman terhadap tujuan organisasi dan tujuan pekerja, perlu dilakukan strategi dalam manajemen pengetahuan. Sehingga pengetahuan dalam tujuan organisasi dalam melakukan implementasi sistem informasi mendapatkan dukungan yang besar dari pekerja karena pekerja memahami dan sesuai dengan tujuan dari individual pekerja. Sehingga, disinilah perlu adanya berbagi pengetahuan setelah mengetahui tipe budaya organisasi yang dimiliki organisasi tersebut.

Kesuksesan dalam berbagi pengetahuan ini akan terbatasi dengan kemampuan pegawai dalam memanajemen sumber daya pengetahuan yang ada untuk dapat disebarkan kepada pegawai lainnya. Sehingga keefektifan dalam berkomunikasi merupakan faktor yang mendukung dalam penyebaran pengetahuan tersebut. Adapun cara untuk mencapai komunikasi yang berguna untuk mendorong kesuksesan dalam berbagi pengetahuan dengan keadaan budaya organisasi yang ada dapat melalui pelatihan yang spesifik dan program pembangunan, pengukuran kinerja competence-based, memberikan rewards, menggali kemampuan pegawai, dan merekomendasikan pegawai yang berkompeten untuk menjadi percontohan bagi pegawai lainnya. Sehingga, dengan meningkatkan kemauan berbagi pengetahuan akan tercipta saling percaya dan meningkatkan kualitas dalam berkomunikasi diantara para pegawai[22].

\section{KESIMPULAN DAN SARAN}

\subsection{Kesimpulan}

Dalam pengimplementasian sistem informasi terdapat hal-hal yang perlu diperhatikan termasuk budaya organisasi yang berpengaruh pada minat pegawai dalam berbagi pengetahuan. Adapun dampak dari budaya organisasi dan berbagi pengetahuan adalah adanya perilaku penolakan oleh pengguna terhadap implementasi sistem. Pengimplementasian sistem informasi pada organisasi merubah sedikit banyaknya proses bisnis yang berjalan dan juga merubah kebiasaan pegawai dalam bekerja. Penolakan yang terjadi pada proses implementasi sistem informasi oleh para pegawai tentunya dikarenakan kurangnya pengetahuan para pegawai tersebut tentang pentingnya dan alasan mengapa sistem itu harus diimplementasikan. Penyampaian pengetahuan tersebut harus bisa dikelola dengan baik, sehingga penyampaian pengetahuan akan sama-rata persebarannya dan mampu menciptakan komitmen yang kuat untuk sama-sama mencapai outcome dari implementasi sistem tersebut. Berbagi pengetahuan akan sangat memudahkan stakeholder dalam mengelola perubahan karena persebaran pengetahuan yang merata dan dapat dipahami maksud dan tujuannya dari keputusan implementasi sistem informasi tersebut.

https://doi.org/10.25077/ TEKNOSI.v4i1.2018.001-008
Pengetahuan yang disebarkan tersebut berupa pengetahuan tacit dan explicit yang dapat diidentifikasi berdasarkan tipe organisasi. Adapun faktor budaya organisasi yang paling berpengaruh dari segi tipe organisasi (struktural : clan, hierarcy, dan sebagainya) yang paling banyak dibahas dari sisi kepercayaan para pegawai dalam berbagi. Dalam sebuah grup atau tim yang kooperatif, akan membangun ikatan saling percaya sehingga dalam berbagi pengetahuan (kolaborasi antara tacit dan explicit) akan lebih mudah dilakukan. Faktor selanjutnya yang menjadi perhatian untuk menciptakan budaya berbagi pengetahuan adalah pemberian penghargaan yang berpengaruh dalam berbagi pengetahuan. Dengan memberikan penghargaan kepada pegawai yang memiliki pengetahuan akan meningkatkan keinginannya dalam mentransferkan, sedangkan yang mendapat pengetahuan juga akan lebih mudah jika diberikan penghargaan atau hadiah. Dengan mengidentifikasi faktor budaya organisasi yang mempengaruhi berbagi pengetahuan ini dapat membantu organisasi yang ingin mencapai tujuan organisasinya dengan menciptakan budaya berbagi pengetahuan. Organisasi yang memiliki kemampuan berbagi pengetahuan yang besar akan lebih baik dalam menanggapi perubahan lingkungan untuk peningkatan kinerja.

\subsection{Saran}

Dari hasil ulasan literatur mengenai hubungan antara budaya organisasi dan berbagi pengetahuan dalam pendukung kesuksesan implementasi sistem informasi, terdapat beberapa hal yang menarik untuk diteliti dan dibahas lebih dalam. Pertama, pengaruh dan peran manajerial (leadership) dalam menciptakan kemauan pegawai untuk berbagi pengetahuannya terutama pengetahuan tacit sehingga meminimalisir terjadinya knowledge loss. Kedua, penelitian terkait berbagi pengetahuan dalam organisasi public dan private, dengan mengidentifikasi budaya organisasi dan bagaimana minat berbagi pengetahuan yang berlangsung dari kedua tipe organisasi tersebut. Sehingga, diharapkan akan ada pembahasan faktor budaya organisasi yang belum dibahas lebih rinci dan keterkaitannya dengan berbagi pengetahuan.

\section{DAFTAR PUSTAKA}

[1] X. Chen, D. Probert, Y. Zhou, and J. Su, "Successful or unsuccessful open source software projects: What is the key?," 2015 Sci. Inf. Conf., vol. 1, no. 34, pp. 277-282, 2015.

[2] S. R. Kathiravelu, N. N. A. Mansor, T.Ramayah, and N. Idris, "Why Organisational Culture Drives Knowledge Sharing?," Procedia - Soc. Behav. Sci., vol. 129, pp. 119-126, 2014.

[3] A. Best, J. Smit, and L. de Faber, "Interventions and their Relation to Organizational culture and Project Management," Procedia - Soc. Behav. Sci., vol. 74, pp. 329-338, 2013.

[4] J.-C. Lee, Y.-C. Shiue, and C.-Y. Chen, "Examining the impacts of organizational culture and top management support of knowledge sharing on the success of software process improvement," Comput. Human Behav., vol. 54, pp. 462-474, 2016.

[5] Z. Shao, Y. Feng, and L. Liu, "The mediating effect of organizational culture and knowledge sharing on transformational leadership and Enterprise Resource Planning systems success: An empirical study in China," 
Comput. Human Behav., vol. 28, no. 6, pp. 2400-2413, 2012.

[6] B. T. Gregory, S. G. Harris, A. A. Armenakis, and C. L. Shook, "Organizational culture and effectiveness: A study of values, attitudes, and organizational outcomes," J. Bus. Res., vol. 62, no. 7, pp. 673-679, 2009.

[7] H. Tohidi and M. M. Jabbari, "Organizational culture and leadership," Procedia - Soc. Behav. Sci., vol. 31, no. 2011, pp. 856-860, 2012.

[8] J.-G. Park and J. Lee, "Knowledge sharing in information systems development projects: Explicating the role of dependence and trust," Int. J. Proj. Manag., vol. 32, no. 1, pp. 153-165, 2014.

[9] L. Andrawina and A. Kurniawati, "Framework for Community of Practice based on SECI method and KM cycle," Int. Conf. ICT Knowl. Eng., pp. 189-193, 2012.

[10] H. W. Chou, Y. H. Lin, H. S. Lu, H. H. Chang, and S. Bin Chou, "Knowledge sharing and ERP system usage in post-implementation stage," Comput. Human Behav., vol. 33, pp. 16-22, 2014.

[11] Y. H. Chen, T. P. Lin, and D. C. Yen, "How to facilitate inter-organizational knowledge sharing: The impact of trust," Inf. Manag., vol. 51, no. 5, pp. 568-578, 2014.

[12] P. E. Swift and A. Hwang, "The impact of affective and cognitive trust on knowledge sharing and organizational learning," Learn. Organ., vol. 20, no. 1, pp. 20-37, 2013.

[13] V. Suppiah and M. Singh Sandhu, "Organisational culture's influence on tacit knowledge-sharing behaviour," J. Knowl. Manag., vol. 15, no. 3, pp. 462477, 2011

[14] S. Durmusoglu, M. Jacobs, D. Zamantili Nayir, S. Khilji, and $\mathrm{X}$. Wang, "The quasi-moderating role of organizational culture in the relationship between rewards and knowledge shared and gained," J. Knowl. Manag., vol. 18, no. 1, pp. 19-37, 2014.

[15] Y. Hakami, S. Tam, A. H. Busalim, A. Razak, and C. Husin, "A REVIEW OF FACTORS AFFECTING THE SHARING OF KNOWLEDGE IN SOCIAL MEDIA," vol. 26 , no. 2, pp. 679-688, 2014.

[16] Z. Shao, T. Wang, and Y. Feng, "Impact of organizational culture and computer self-efficacy on knowledge sharing," Ind. Manag. Data Syst., vol. 115, no. 4, pp. 590-611, 2015.

[17] V. Suppiah and M. Singh Sandhu, "Organisational culture ' $\mathrm{s}$ influence on tacit knowledge-sharing behaviour," J. Knowl. Manag., vol. 15, no. 3, pp. 462477, 2011.

[18] L. Makhubele, J. Kinyua, and R. Kekwaletswe, "The effect of organizational, external, social, trust, information technology factors and knower's attitude on knowledge sharing: A case of financial service firm in South Africa," 2012 2nd Int. Conf. Digit. Inf. Commun. Technol. its Appl. DICTAP 2012, pp. 498-503, 2012.

[19] M. Z. Islam, S. M. Jasimuddin, and I. Hasan, "Organizational culture, structure , technology infrastructure and Empirical evidence from MNCs based in," VINE, vol. 45, no. 1, pp. 67-88, 2015.

[20] H. A. Al Mehairi, "Empowering knowledge sharing behaviours through means oriented vs. goal oriented cultures: The impact of organizational culture on knowledge sharing," Proc. 2013 10th Int. Conf. Inf. Technol. New Gener. ITNG 2013, pp. 702-705, 2013.

[21] A. Titi Amayah, "Determinants of knowledge sharing in a public sector organization," J. Knowl. Manag., vol. 17, no. 3, pp. 454-471, 2013.

[22] H. Abdul-Jalal, P. Toulson, and D. Tweed, "Knowledge Sharing Success for Sustaining Organizational Competitive Advantage," Procedia Econ. Financ., vol. 7, no. Icebr, pp. 150-157, 2013.

\section{BIODATA PENULIS}

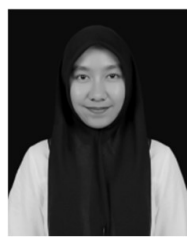

Nina Fadilah Najwa

Nina Fadilah Najwa, lahir di Pekanbaru, 30 Mei 1994. Menyelesaikan pendidikan Program Sarjana Sistem Informasi (S1) pada Fakultas Sains dan Teknologi UIN SUSKA Riau. Saat ini, penulis sedang melanjutkan Program Pascasarjana Magister Sistem Informasi (S2) pada Fakultas Teknologi Informasi dan Komunikasi di Institut Teknologi Sepuluh Nopember Surabaya.

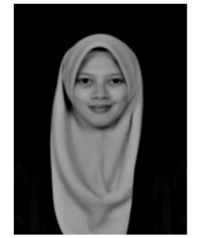

Afifah Nurul Izzati

Afifah Nurul Izzati, lahir di Ponorogo, 6 Juli 1993. Menyelesaikan pendidikan Program Sarjana Sistem Informasi (S1) pada Fakultas Rekayasa Industri Universitas Telkom. Saat ini penulis sedang menempuh pendidikan Program Pascasarjana Magister Sistem Informasi (S2) pada Fakultas Teknologi Informasi dan Komunikasi Institut Teknologi Sepuluh Nopember, Surabaya. Penulis dapat dihubungi melalui email: fifah.afifah26@gmail.com 